\title{
Luther og filosofien
}

"Efter reformationen var Luther de tyske filosoffers modermælk." Sådan indledte den italienske filosof og Lutherforsker Stefano Leoni sit seminarindlæg på den 13. Internationale Kongres for Lutherforskning i Wittenberg i år. Har Leoni ret, er det påfaldende, at Luther stort set ikke optræder i filosofihistoriske indføringer. Årsagerne kan være mange. Luthers egne hårde udfald mod "filosofien" bærer sikkert en del af skylden.

Dette nummers bidrag om Luther og filosofien stammer alle fra et seminar på Aarhus Universitet, der som en del af optakten til Rethink Reformation-konferencen 1.-3 november i år stillede spørgsmålet om Luthers betydning for filosofien. Dansk Teologisk Tidsskrift har valgt at markere dette års reformationsjubilæum ved at udgive let reviderede bidrag fra dette seminar dels som en indføring i spørgsmålet om forholdet mellem Luther og filosofien, dels som en tydeliggørelse af nødvendigheden af yderligere forskningsmæssig opmærksomhed på dette felt.

Anders Moe Rasmussen foreslår i den første artikel at læse Kant som filosofiens Luther. Med en begrundet skepsis over for en direkte indflydelse fra Luther i Kants tænkning - dertil er Kants tænkning alt for ny - finder Moe Rasmussen ikke desto mindre et aftryk af Luthers afregning med filosofien og fornuften i Kants filosofi. De deler en fælles grundforudsætning: en afståen fra at være Gud lig. Hos Kant betyder det ikke et opgør med fornuften, men en skelnen mellem legitim og illegitim brug. Så skønt forbindelsen mellem Luther og Kant ikke er direkte, lader hverken Kants filosofi eller den tænkning, der fulgte i kølvandet sig forstå uden reformationens nybrud.

Forholdet mellem fornuft og tro er også omdrejningspunkt for Pia Søltofts behandling af forholdet mellem Luther og Kierkegaard i den efterfølgende artikel. Hun viser, hvordan Kierkegaard både forholder sig afvisende til, hvad han ser som en "udialektisk" bestemmelse af troen hos Luther, fordi den overser troens forbindelse med refleksionen, og hvordan han tilslutter sig Luther i betoningen af tilegnelsens og samvitighedens rolle.

I Marius Timmann Mjaalands artikel om "Ateismens topologi" griber forfatteren tilbage til Luthers tanke om deus absconditus som en mulig baggrund for den moderne ateisme, fordi den involverer 
et opgør med traditionel metafysik. Mjaaland følger et spor, der går gennem Hegel, Nietzsche og Heidegger samt Pascal, Kant, Jacobi og Derrida. Mjaaland argumenterer for nødvendigheden af mere indgående studier i de teologiske og filosofiske forudsætninger for ateismen, netop fordi den moderne ateismens fremkomst var afhængig af et stabilt kristent hegemoni, som er tabt i en postkristen kultur.

Nummerets sidste artikel falder uden for temaet, idet den nok omhandler forholdet mellem kristendom og filosofi, men ikke Luther. Jesper Tang Nielsen giver her Troels Engberg-Pedersens nye bog John and Philosophy en grundig læsning og diskussion. Omdrejningspunktet er den johannæsiske og stoiske forstålse af pneuma. Forfatteren argumenterer for en mere kompleks forståelse af den johannæiske brug af begrebet pneuma, der samtidig svækker den hævdede forbindelse til stoisk tankegang.

For såvel Luther som Johannes gælder det, at spørgsmålet om deres mellemværende med filosofien langt fra er endeligt afhandlet.

Bo Kristian Holm 